\title{
Lutzomyia longipalpis s.I. in Brazil and the impact of the Sao Francisco River in the speciation of this sand fly vector Iliano V Coutinho-Abreu ${ }^{\dagger 1,4,5}$, Ivan V Sonoda ${ }^{\dagger 1}$, Jose A Fonseca ${ }^{2}$, Marcia A Melo ${ }^{3}$, Valdir Q Balbino ${ }^{\dagger 1}$ and Marcelo Ramalho-Ortigão*†4,5
}

\begin{abstract}
Address: ${ }^{1}$ Departamento de Genética, Centro de Ciências Biológicas, Universidade Federal de Pernambuco, Recife, Brazil, ${ }^{2}$ Universidade Federal do Piauí, Teresina, Brazil, ${ }^{3}$ Universidade Federal de Campina Grande, Campina Grande, Brazil, ${ }^{4}$ Department of Biological Sciences, University of Notre Dame, Notre Dame, IN 46556, USA and ${ }^{5}$ Department of Entomology, K-State University, 123 Waters Hall, Manhattan, KS 66506-4004, USA

Email: Iliano V Coutinho-Abreu - ivieirac@nd.edu; Ivan V Sonoda - sonodai@cpqrr.fiocruz.br; Jose A Fonseca - castro@ufpi.br; Marcia A Melo - melo@pesquisador.cnpq.br; Valdir Q Balbino - valdir@ufpe.br; Marcelo Ramalho-Ortigão* - mortigao@nd.edu

* Corresponding author †Equal contributors
\end{abstract}

Published: 3 October 2008

Parasites \& Vectors 2008, I:37 doi:10.1 186/1756-3305-1-37
Received: 24 September 2008

Accepted: 3 October 2008

This article is available from: http://www.parasitesandvectors.com/content/l/1/37

(c) 2008 Coutinho-Abreu et al; licensee BioMed Central Ltd.

This is an Open Access article distributed under the terms of the Creative Commons Attribution License (http://creativecommons.org/licenses/by/2.0), which permits unrestricted use, distribution, and reproduction in any medium, provided the original work is properly cited.

\begin{abstract}
In our recently published article "Lutzomyia longipalpis s.l. in Brazil and the impact of the Sao Francisco River in the speciation of this sand fly vector" by lliano V. Coutinho-Abreu et al. a sentence located in paragraph 8 in the Discussion section had its meaning altered due to the improper insertion of three words.
\end{abstract}

\section{Correction}

In our recently published article a sentence located in paragraph 8 in the Discussion section had its meaning altered due to the improper insertion of three words [1]. The paragraph published reads: "The reduced gene flow between sibling species and moderate genetic differentiation between groups $<10^{\circ} \mathrm{S}$ and $>10^{\circ} \mathrm{S}$ are consistent with a distribution pattern likely driven by the Sao Francisco River. Additionally, the estimated time of the divergence of these two groups coincides with the change of the river course. However, this divergence cannot be associated with reduced gene flow as mitochondrial DNA is prone to introgress through incipient species boundaries (reference 50 in the original article), and as demonstrated via $c y t b$ gene analysis of $L u$. longipalpis s.l. sympatric cryptic species (reference 51 in the original article). Taken together, the data suggest that the Sao Francisco River is a significant geographic barrier between populations of Lu. longipalpis s.l., and could also have contributed to the current level of population diversity seen for this sand fly."
The paragraph should have read "The reduced gene flow and moderate genetic differentiation between groups < $10^{\circ} \mathrm{S}$ and $>10^{\circ} \mathrm{S}$ are consistent with a distribution pattern likely driven by the Sao Francisco River. Additionally, the estimated time of the divergence of these two groups coincides with the change of the river course. However, this divergence cannot be associated with reduced gene flow between sibling species as mitochondrial DNA is prone to introgress through incipient species boundaries (reference 50 in the original article), and as demonstrated via $c y t b$ gene analysis of $L u$. longipalpis s.l. sympatric cryptic species (reference 51 in the original article). Taken together, the data suggest that the Sao Francisco River is a significant geographic barrier between populations of Lu. longipalpis s.l., and could also have contributed to the current level of population diversity seen for this sand fly."

Additionally, the Figure 3 legend (Mantel Test) was erroneously inserted into Figure 4 (Minimum Spanning Networks (MSN) and vice versa. 
We apologize for any confusion these may have caused.

\section{References}

I. Coutinho-Abreu IV, Sonoda IV, Fonseca JA, Melo MM, Balbino VQ, Ramalho-Ortigão M: Lutzomyia longipalpis s.l. in Brazil and the impact of the Sao Francisco River in the speciation of this sand fly vector. Parasit Vectors 2008, I:16.

Publish with Bio Med Central and every scientist can read your work free of charge

"BioMed Central will be the most significant development for disseminating the results of biomedical research in our lifetime. " Sir Paul Nurse, Cancer Research UK

Your research papers will be:

- available free of charge to the entire biomedical community

- peer reviewed and published immediately upon acceptance

- cited in PubMed and archived on PubMed Central

- yours - you keep the copyright

Submit your manuscript here:

http://www.biomedcentral.com/info/publishing_adv.asp 